\title{
PRECAUTION, SCIENCE, AND LEARNING WHILE DOING IN NATURAL RESOURCE MANAGEMENT
}

\author{
Holly Doremus*
}

\begin{abstract}
Dealing with uncertainty is widely recognized as the key challenge for environmental and natural resource decisionmaking. Too often, though, that challenge is considered only from an ex ante perspective which treats uncertainty as an invariant feature that must be accounted for but cannot be changed. With respect to many natural resource management decisions, that picture is misleading. Decisions are often iterative or similar, providing significant opportunities for learning. Where such opportunities are available and inaction is not feasible or desirable, learning while doing can provide the benefits of both the precautionary principle and scientific decisionmaking while minimizing the key weaknesses of each. After highlighting the benefits of a learning-while-doing approach to natural resource management, this paper briefly addresses how management agencies might be encouraged to adopt such an approach.
\end{abstract}

INTRODUCTION

I. LEARNING CONNECTS PRECAUTION WITH SCIENCE ......550

A. The Precautionary Principle Should Encourage Learning .....550

1. The Conventional Formulation of Precaution...............550

2. Learning Can be Precautionary ..................................553

B. Science Provides a Process for Structured Learning ..............557

1. The Relationship Between Science and Precaution .....558

2. The True Strength of Science Lies in Its Capacity to Promote Learning.........................................................562

C. The Synergistic Potential of Precaution and Science..............563

1. How Science Can Improve Precaution .........................563

"Professor of Law, University of California, Davis. It is a great pleasure to participate in this symposium honoring Bill Rodgers, one of the true giants of the field. Bill's scholarship, advocacy, and teaching are all inspirational. I know I'll never achieve his broad mastery of environmental and natural resource law, but I aspire every day to do my own work with something approaching the grace and good humor that characterize Bill's. As just one example, who but Bill would have thought of publishing "environmental law trivia tests" that teach serious lessons about environmental conflicts in a humorous way? See W. Rodgers, Environmental Law Trivia Test, 9 TUlane ENVTL. L.J. 75 (1995); William H. Rodgers, Jr., Environmental Law Trivia Test No. 2, 22 B.C. EnVtl. AfF. L. ReV. 807 (1995); William H. Rodgers, Jr., A Superfund Trivia Test: A Comment on the Complexity of Environmental Laws, 22 ENVTL. L. 417 (1992). I also want to acknowledge the many ways in which my thinking about the relationship between science and law has been influenced by discussions and collaborations with Dan Tarlock (another giant of the field) and David Adelman. Finally, I am grateful for helpful comments on this paper from Albert Lin, Peter Lee, Howard Latin, and Pete Holloran. 
2. How Precaution Can Improve Science ......................566

II. A FRAMEWORK FOR LEARNING WHILE DOING IN RESOURCE MANAGEMENT …............................................568

A. Adaptive Management By Any Other Name? .......................568

B. What Does Learning While Doing Require, and How Can We Get There? ...............................................................570

1. Agency Discretion and Leadership .............................570

2. Legislatures and Budgeting........................................572

3. Courts and Incentives for Learning.............................573

\section{INTRODUCTION}

Uncertainty is the unifying hallmark of environmental and natural resource regulation. Dealing with uncertainty has been a major topic of academic interest for decades, but the debate has produced no firm or general conclusions.

Two alternatives frequently put forward for dealing with uncertainty are the precautionary principle and scientific principles. Typically these two are presented as standing in opposition. Precautionary decisionmaking is described as favoring regulation when there is some evidence of risk to human health or the environment. Scientific decisionmaking is described as requiring proof of harm to support regulation. In either case, the emphasis is almost always on a single forward-looking decision that must be made based on a fixed level of available information.

In this essay, I argue that a clearer picture of the challenges of uncertainty for natural resource management requires a wider temporal scope and additional degrees of freedom. Natural resource decisions typically do not present a single choice between two alternatives that, once made, remains fixed for all time. Far more often, multiple related decisions must be made over a long period of time, on the scale of years or even decades. Furthermore, the choices are more nuanced than "on" versus "off" or "open" versus "closed." There is room for a variety of conditions and limitations. Some decisions, such as how to operate a series of dams and reservoirs, what terms to include in a water pollution discharge permit, or whether and under what conditions to renew a public lands grazing lease, are explicitly temporary and therefore must be addressed repeatedly. Others are individually irreversible and therefore made only once, but belong to classes of decisions sufficiently 
similar that information gained from one can usefully inform another. Examples include salvage logging and wetlands filling.

One more detail should be added to this picture. Much of the discussion of precaution versus science has been framed by the specific context of regulating novel technologies or products. In that context, preserving the status quo may have economic or human health consequences, but it generally appears to protect the environment. Natural resource management is different. A legacy of past decisions made without regard for nature means that the status quo is often both bad for the environment and strongly resistant to change. The large water projects that dot the west, for example, have brought much of the region's aquatic fauna to the brink of extinction. Because they provide water to both cities and farms, however, shutting them down is not a realistic short-term option. In other situations, the need for action to correct past decisions is clear, but the effects of potential restoration efforts are not. Decades of aggressive fire suppression, for instance, have transformed open Ponderosa forests into thickets of fir. These altered forests pose a fire risk to nearby human communities, but are also inhospitable to some species native to the Ponderosa system. How best to reduce fire risk while restoring native ecological communities is unclear.

This more accurate picture of the decisionmaking task suggests that we need not simply accept high levels of uncertainty. In at least some cases, it is possible to reduce uncertainty over time in ways that are relevant to subsequent iterations or related decisions. From that perspective, the most important challenge of uncertainty is not always how it should be accounted for in an initial decision. How to reduce uncertainty through learning, in order to improve later rounds of decisionmaking, may be more important. That policy choices can and should encourage development of new technology is a commonplace assumption in the pollution control context, where "technology forcing" is an accepted policy goal. ${ }^{1}$ By the same token, "knowledge forcing"encouraging the development of additional knowledge to support future

1. For descriptions of the role and limits of technology forcing in environmental regulation, see, e.g., Christopher T. Giovinazzo, Defending Overstatement: The Symbolic Clean Air Act and Carbon Dioxide, 30 Harv. EnVtL. L. Rev. 99, 107, 114 (2006); Carol M. Rose, Scientific Innovation and Environmental Protection: Some Ethical Considerations, 32 ENVTL. L. 755, 768-69 (2002); Thomas O. McGarity, Radical Technology-Forcing in Environmental Regulation, 27 LOY. L,A. L. REV. 943 (1994). 
decisions-should be a goal of natural resource policy. Yet active learning is rarely incorporated into the resource management process.

For iterative or related decisions, where there is no "safe" choice, precaution and science are not in tension. Both point us toward an incremental framework for decisionmaking that emphasizes learning. We might call that framework adaptive management, but for reasons explained later I prefer the more descriptive phrase "learning while doing." In this paper, I first explain how learning while doing can bring the best of both precaution and science to bear on natural resource management, while cabining the most significant shortcomings of each. I then detail what I mean by learning while doing, and how it differs from common understandings of adaptive management and "learning by doing." Finally, I offer some thoughts on how our resource management institutions might be structured to better support learning while doing, and what executive, legislative, and judicial actors can do to encourage knowledge forcing.

\section{LEARNING CONNECTS PRECAUTION WITH SCIENCE}

Precautionary and scientific approaches to decisionmaking are often characterized as distinct, and even incompatible. Although the two approaches are indeed distinct, in many situations they are not only compatible but also synergistic. For difficult natural resource management choices, precaution and science frequently point in precisely the same direction: toward assigning a key role to learning while acting incrementally.

\section{A. The Precautionary Principle Should Encourage Learning}

Properly understood, the precautionary principle mandates attention to learning. That element, although it is implicit in the idea of precaution, is underappreciated, leaving the role of learning undertheorized. For many natural resource decisions, the most sensible form of caution is learning while acting.

\section{The Conventional Formulation of Precaution}

The most frequently cited formulation of the precautionary principle is found in the 1992 Rio Declaration:

Where there are threats of serious or irreversible damage, lack of full scientific certainty shall not be used as a reason for 


\section{postponing cost-effective measures to prevent environmental} degradation. $^{2}$

The rationale behind the precautionary principle is simple: "better safe than sorry." The precautionary intuition responds to three features typical of environmental problems. First, people are prone to pay too little attention to certain types of risk. New technologies or activities may harm human health or the environment in unexpected ways. Those harms may not become manifest for many years after the events that cause them. Human cognitive biases and the structure of political institutions make it likely that uncertain future environmental costs will have less impact on decisions than certain and immediate economic consequences. ${ }^{3}$ Second, once set in motion, environmental impacts can be difficult or impossible to reverse on human time scales. We are already inexorably committed, for example, to some degree of global warming because of fossil fuel consumption since the industrial revolution. Less drastically, foreign species that have escaped containment and propagated in new environments, such as the European annual grasses that now dominate California's grasslands, are essentially impossible to eradicate. The only way to have avoided these harms and others like them would have been to restrict the activities that cause them well in advance of any clear proof of harm. Third, it is often difficult to unring the policy bell once choices are made. Some decisions are quite literally irreversible. An old-growth tree, once felled, cannot be pasted back together. Other trees may mature to replace it, but that can take hundreds of years. Other decisions, like the annual determination of allowable catch in a fishery, appear entirely reversible. They too inevitably become sticky, however, as the institutions developed to support them solidify and people build expectations around them. It is almost always much easier to bar a new use than to withdraw approval of an established one, ${ }^{4}$ and to forego construction than to remove

2. Rio Declaration on Environment and Development, June 14, 1992, U.N. Doc. A/CONF.151/26/Rev.1 (Vol. I), princ. 15, reprinted in 31 I.L.M. 874, 879 (1992).

3. David A. Dana, A Behavioral Economic Defense of the Precautionary Principle, 97 Nw. U. L. REV. 1315, 1320-26 (2003). Professor Robert Percival has also noted the political challenges of regulating before harms become widely apparent. Robert V. Percival, Who's Afraid of the Precautionary Principle?, 23 PACE ENVTL. L. REV. 21, 36-78 (2005-2006).

4. The practice of "grandfathering" existing facilities or uses in order to reduce political resistance to new regulations is well established. The costs of that practice have recently become clear, as old electric power plants continue to spew air pollutants. Shi-Ling Hsu, The Real Problem with New Source Review, 36 ENVTL. L. REP. 10,095 (2006). Percival cites another illustration: even 
existing infrastructure. Because "an ounce of prevention is worth a pound of cure," it is not surprising that most advocates of the precautionary principle emphasize its preventive role.

Context has pushed discussion of precaution even further in that direction. The precautionary principle has been expounded primarily as a way to deal with novel activities or technologies that pose poorly understood risks. ${ }^{5}$ Preventive precaution is a natural fit for that context, reminding us to think hard in advance about what could go wrong, encouraging regulatory action before activities become too firmly entrenched, and providing a way out of the regulatory paralysis that can follow from endless quibbles about whether the available scientific information meets some required threshold. ${ }^{6}$

But caution, as Christopher Stone reminds us, can mean different things in different contexts. ${ }^{7}$ The conventional formulation of the precautionary principle focuses on one particular type of caution: not allowing potentially harmful agents through the regulatory starting gate until we have reasonable confidence that their harms can be contained within acceptable limits. Although it leaves room for later reexamination-the gate can always be opened if proponents of the new substance or activity demonstrate its safety-that image focuses concern strongly on a single decision, to open or close the gate, and indeed on a single feature of that decision, how to account for uncertainty. ${ }^{8}$ The

in the infamous Corrosion Proof Fittings v. EPA case, which overturned EPA's decision to phase out existing asbestos-containing products, the court upheld the agency's ban on introducing new uses of asbestos. Percival, supra note 3, at 74; Corrosion Proof Fittings v. EPA, 947 F.2d 1201, 1229 (5th Cir. 1991).

5. See, e.g., Christopher D. Stone, Is There a Precautionary Principle?, 31 ENvTL. L. ReP. $10,790,10,793$ (2001) ("The precautionary principle is motivated by concern for a new generation of risks, in large measure connected with the novelty of emerging technologies.").

6. Bernard D. Goldstein \& Russellyn S. Carruth, Implications of the Precautionary Principle for Environmental Regulation in the United States: Examples from the Control of Hazardous Air Pollutants in the 1990 Clean Air Act Amendments, 66 LAW \& CONTEMP. PROBS., Autumn 2003, at $247,248-49$ ("An all-too-familiar ploy of industry is to obstruct or delay risk-based regulation by requesting more scientific study or challenging its scientific validity in the courts.").

7. Stone, supra note 5 , at 10,792-10,799. Cass Sunstein also notes that precaution appropriately takes different forms in different contexts. He identifies a "Funding More Research Precautionary Principle," an "Information Disclosure Precautionary Principle," an "Economic Incentives Precautionary Principle," and a "Prohibitory Precautionary Principle" as fitting different circumstances. Cass R. Sunstein, Laws of Fear: Beyond the Precautionary Principle 120-21 (2005).

8. I suspect that the prevailing static vision of decisionmaking in legal academic thinking derives in part from the fact that legal training focuses so heavily on judicial opinions. Litigation is a context in which decisions must be made on the basis of the information available at a single point 
focus, perhaps unconsciously, is on ex ante information gathering and prediction, almost to the exclusion of ex post monitoring and reconsideration. ${ }^{9}$ The type of precaution produced by this ex ante focus is not necessarily bad or misplaced, but it is surely incomplete.

\section{Learning Can be Precautionary}

In fact, the precautionary principle implicitly requires openness to learning. Ideally, it provides "a framework for learning in the face of uncertainty." 10 John Applegate makes this point when he describes "iteration," the periodic revisiting of decisions, as an essential feature of a precautionary approach:

Action taken on the basis of uncertainty is necessarily tentative, and the principle thus implies that some action will be taken by someone to reduce the uncertainty to levels appropriate for taking final regulatory action."

Not only is a willingness to revisit decisions an inescapable element of the precautionary approach, it "makes early precautionary action more palatable and indeed more sensible." 12 Given uncertainty, we know that any regulatory decision might be wrong. We should, therefore, seek to increase our knowledge over time and be prepared to revisit decisions as justified by new information.

Still, as Professor Applegate notes, the ways that learning might play a role in precautionary decisionmaking have rarely been emphasized. ${ }^{13}$

in time, no matter how limited that information may be, and those decisions are not generally subject to revisiting later in light of additional information. Regulation is very different; in that context, we typically enjoy the opportunity for a policy cycle, in which successive decisions are deliberately revisited over time.

9. The ex ante focus of the conventional understanding of the precautionary principle is hardly unique in environmental decisionmaking. Brad Karkkainen has described in detail how requirements for environmental assessment have produced only limited learning because they only look forward. Bradley C. Karkkainen, Toward a Smarter NEPA: Monitoring and Managing Government's Environmental Performance, 102 COLUM. L. REv. 903 (2002).

10. Sheila Jasanoff, Between Risk and Precaution - Reassessing the Future of GM Crops, $3 \mathrm{~J}$. RISK RESEARCH 277, 277 (2000).

11. John S. Applegate, The Taming of the Precautionary Principle, 27 WM. \& MARY ENVTL. L. \& POL'Y REV. 13, 20 (2002).

12. Id. at 75-76. See also Sidney A. Shapiro and Robert L. Glicksman, RISK Regulation AT RISK (2003) (promoting pragmatic "back-end" adjustment of regulation as a way to improve both substantive outcomes and political viability).

13. Applegate, supra note 11 , at 43 (describing iteration as "the relative newcomer" to the precautionary principle). 
Discussion of learning comes in only two forms, each assuming that the only relevant decision is to act or not act. Supporters of the precautionary principle like to extol the incentives for new development or release of new information provided by putting the burden of proof on proponents of new activities or technologies. ${ }^{14}$ From the other side, skeptics occasionally remind advocates of a precautionary approach of the need to "at the least, discuss a research program that would, after the precautionary action, let us know whether the action was appropriate and beneficial." 15

Conspicuously absent from most discussions of the precautionary principle is the concept that the decision to act does not end the opportunity for caution. Suppose, for example, that the lights go out suddenly one night while I am sitting in my living room, plunging me into darkness. Putting caution above all else, I could remain in my chair. That would keep me safe from bumping into walls, stubbing my toes on the furniture, or tripping over toys scattered on the floor. If there is a high probability that the problem is in the utility lines outside the home, staying seated is probably the wisest choice, at least in the short run. Getting up subjects me to some level of risk but does nothing to get the lights back on. If there's a good chance that the cause of the outage is a blown fuse in the house, though, getting up starts to sound better. The gatekeeping decision, to get out of the chair, is not the only chance to exercise caution. Once up I can proceed cautiously, feeling ahead with my arms and shuffling my feet to minimize the chance that I will suffer harm.

A significant proportion of natural resource management decisions calls for moving in the dark, rather than sitting still. Learning while doing, rather than freezing the status quo, is the appropriate type of caution when significant uncertainty is accompanied by two additional elements. First, it must be reasonable to believe that uncertainty can be reduced in ways that matter for management choices over management-

14. Dana, supra note 3, at 1328; Wendy E. Wagner, Commons Ignorance: The Failure of Environmental Law to Produce Needed Information on Health and the Environment 53 DUKE L.J. 1619, 1741-42 (2004); Hildreth et al., Roles for a Precautionary Approach in U.S. Marine Resources Management, NATURAL RESOURCE \& ENV'T, Summer 2004, at 64, 65.

15. Goldstein \& Carruth, supra note 6, at 258. See also Gail Chamley \& E. Donald Elliott, Risk Versus Precaution: Environmental Law and Public Health Protection, 32 EnVTL. L. ReP. 10,363, 10,365 (2002) ("Proponents of the precautionary principle have yet to clarify how regulation based on precaution in the absence of adequate science can be revisited and changed when better science becomes available."). 
relevant time periods, without incurring unacceptable risks of harm. In the electric outage example, I believe I can figure out the way to a flashlight or the circuit breaker box while risking only a bruise or stubbed toe. If the situation were different, such that a wrong step might send me hurtling off a high tower, I would certainly be less inclined to move at all. Second, inaction must be either impractical or itself risky. If a blown fuse in my house has interrupted the power supply, power will never be restored unless someone in the household gets up. Inaction is safe, but cannot address the problem. Alternatively, suppose that a member of the household relies on electrically-powered medical devices which can run on battery back-up power only for a short time. In that situation, inaction would be safe in one sense, but very risky in another. The choice between learning while doing and inaction as forms of precaution generally depends upon the relative risks of action and inaction, the extent of external pressure for action, and the extent to which action can be taken in incremental, reversible steps. Those factors vary with both the context and the perspective of the observer.

At least three classes of natural resource management decisions justify a precautionary approach that emphasizes learning while doing. In the first, inaction or maintenance of the status quo itself presents significant risks to the natural world. This situation is more common than might be expected, because past decisions have greatly modified many natural systems. A well-known example is fire suppression on national forest lands. Much of the arid west burned periodically before Anglo-American settlement. Characteristic fire regimes varied widely. In some areas, low-intensity fires swept through as often as once or twice a decade. Others were subject to intense, stand-replacing fires at intervals of a hundred years or more. ${ }^{16}$ Since the early twentieth century, however, the U.S. Forest Service has aggressively sought to suppress fire on the lands under its supervision. ${ }^{17}$ Fire exclusion has drastically altered the ecology of acres of lands with a history of frequent lowintensity fires, turning them from open stands into thickets at risk of much higher-intensity crown fires. ${ }^{18}$ In areas with such altered fire regimes,

16. Robert B. Keiter, The Law of Fire: Reshaping Public Land Policy in an Era of Ecology and Litigation, 36 ENVTL. L. 301, 313-14 (2006).

17. Id. at 304-308.

18. Noss et al., supra note 16 , at 483 . 
[k]ey structural elements (e.g. old "veteran" trees), terrestrial and aquatic biodiversity, and habitats of many threatened and endangered species are already greatly diminished and at continuing risk of loss. ${ }^{19}$

Leaving these forests in their current condition carries substantial risks for the environment, as well as for nearby human communities, but no consensus has developed as to the best way to address those risks.

The second class of decisions that call for precautionary action rather than stasis is those for which inaction is impractical for socioeconomic reasons. The difficulty of reversing historic environmentally-damaging decisions increases in parallel with the reliance of human communities on those decisions. While we might not take those actions in the first place today, we cannot undo them overnight. Consider, for example, operation of the facilities that transport immense volumes of water from northern to southern California through the Sacramento-San Joaquin Delta. The combined operations of the federal Central Valley Project and State Water Project, which can move eleven thousand cubic feet of water per second, have drastically altered the ecology of the Delta. The massive Project pumps divert about 5,000,000 acre-feet of freshwater annually. That water irrigates nearly $3,000,000$ acres of farmland ${ }^{20}$ and provides about forty percent of California's drinking water, ${ }^{21}$ contributing to drinking water systems that serve $23,000,000$ people, nearly two-thirds of California's population. ${ }^{22}$ It is highly unlikely that the Delta pumps will be shut down for prolonged periods in the near term, even though that might be the best solution for the environment. ${ }^{23}$

19. Id. at 481 .

20. URS Corp., Status and Trends of Delta-Suisun Services, Report for California Department of Water Resources, Public Review Draft 19 (Mar. 2007), available at http://www.deltavision.ca.gov/docs/DV_Status_and_Trends.pdf.

21. Elizabeth Ann Rieke, The Bay-Delta Accord: A Stride Toward Sustainability, 67 U. CoLO. L. REV. 341, 344 (1996).

22. URS Corp., supra note 20 , at 19.

23. In fact, the pumps have operated for years without a state permit to take endangered species, apparently in flagrant violation of state law. Even that revelation is not likely to shut them down soon, however. Early in 2007, a California trial court ruled that the State Water Project pumps cannot continue to operate without a California Endangered Species Act permit. Judgment Granting Peremptory Writ of Mandate, Watershed Enforcers v. Cal. Dept. of Water Res., No. RG06292124 (Super. Ct., County of Alameda, Apr. 18, 2007), available at http://apps.alameda.courts.ca.gov/fortecgi/fortecgi.exe?ServiceName=DomainWebService\&Templa teName=index.html. The Department of Water Resources has vigorously objected to that ruling, emphasizing the impacts that shutting down the pumps would have on municipal and agricultural water supplies. Declaration of Carl Torgerson in Support of Request for Hearing, Watershed 
Other steps might provide as much or more benefit to Delta species as shutting down the pumps. Patterns of water flow through or around the Delta might be changed, spawning habitats might be improved, and the salinity in the western Delta might be allowed to vary more than it currently does. ${ }^{24}$ There is plenty to learn about the response of Delta species and systems to these and other management choices. Focusing on the pumps alone hides other impacts that might be just as important, and more amenable to correction.

The third set of decisions calling for learning while doing is less obvious: those which, although individually small and essentially irreversible, are repeated often enough to produce cumulatively significant impacts, and over a long enough period of time to permit learning and adjustment. Examples include the approval of individual salvage logging or forest thinning projects, the granting of permits to fill wetlands, and the issuance of permits allowing the incidental take of endangered species. Collectively, decisions like these offer significant opportunities for learning.

\section{B. Science Provides a Process for Structured Learning}

Virtually everyone involved in debates about environmental and natural resource policy in the United States emphasizes the need for science to drive decisions. The policy debates, however, reveal little

Enforcers v. Cal. Dept. of Water Res., No. RG06292124 (Super. Ct., County of Alameda, Apr. 10, 2007), available at http://www.publicaffairs.water.ca.gov/newsreleases/2007/041107impacts3.pdf. The state trial court's ruling has been stayed pending appeal. See Mike Taugher, Water Agency Appeals Pumping Ruling, CONTRA COSTA TIMES, May 8, 2007, at A10; Memorandum from Department of Water Resources to L. Ryan Broddrick, Department of Fish and Game (May 7, 2007), available at http://www.publicaffairs.water.ca.gov/newsreleases/2007/050807cesa_memo.pdf. Another wrinkle was added by a federal court ruling that the federal permit allowing incidental take of the Delta smelt was invalid. Order Granting in Part and Denying in Part Plaintiffs Motion for Summary Judgment, NRDC v. Kempthorne, No. 1:05-CV-01207 OWW (TAG) (May 25, 2007), available at http://www.earthjustice.org/library/legal_docs/decision-on-delta-smelt-biop.pdf. The federal court, however, refused to enjoin pumping. In early summer 2007, the Department of Water Resources did voluntarily curtail pumping for nine days, but ramped it up as the irrigation season kicked in and municipalities began to suffer shortages. See Matt Weiser, Delta Pumps Halted, SaCramento BeE, June 1, 2007, at Al; Mike Taugher, Water Crisis May Not Be Over, TRIVALley Herald, July 3, 2007. As of early July 2007 , the pumps were operating amid concern that another temporary halt might be imminent. See id; Eric Bailey, Delta on the Brink, Panelists Warn, Los ANGELES Times, July 3, 2007.

24. For an outstanding overview of Delta management issues, see JAY LUND ET AL., ENVISIONING FUTURES FOR THE SACRAMENTO-SAN JOAQUIN DELTA (2007). 
understanding of the nature of scientific inquiry, or sensitivity to the strengths and limitations of science. Shared misunderstandings make it easy for those skeptical of environmental protection to characterize the precautionary principle as anti-scientific. Although that charge is mistaken, it is invited by the prevailing front-loaded descriptions of the precautionary principle. When both the nature of precaution and the nature of scientific inquiry are more clearly highlighted, it becomes clear that the two are fully consistent, joined by a commitment to learning. While precaution provides the motivation for learning, science provides the method.

\section{The Relationship Between Science and Precaution}

The push for scientific decisionmaking is driven in large part by a quest for objectivity. Science is popularly supposed to be free of emotion or bias, a characteristic that may seem especially important in natural resource policy, where the depth of value conflicts across society is painfully apparent. Some participants in environmental debates may genuinely be hoping to find scientific approaches that rise above those conflicts. $^{25}$ Some may be looking for ways to counter known shortcomings of human cognition. ${ }^{26}$ Others may simply hope to exploit public faith in science to hide the role their own values play in motivating their positions. ${ }^{27}$

The reification of scientific decisionmaking as objective and unbiased dovetails nicely with one of the main criticisms of the precautionary principle: that its amorphousness invites subjectivity that renders it "subject to abuse by policy makers." ${ }^{28}$ It is not surprising that critics of

25. See, e.g., Michael Oppenheimer, Defining Dangerous Anthropogenic Interference: The Role of Science, the Limits of Science, 25 RISK ANALYSIS 1399, 1401 (2005) (noting the "strong interest [among climate change commentators] in establishing a category of risk that circumvents or at least limits the complications inherent in drawing on the social science perspective or incorporating value judgments.")

26. Cass Sunstein, for example, seeks to replace the precautionary principle, which he sees as embodying "the various cognitive limitations that people face in thinking about risks," with a more rational, cost-benefit analysis approach. SUNSTEN, supra note 7, at 62, 129.

27. Perhaps the most infamous recent example of this phenomenon is the notorious memo urging Republican politicians to exploit the political power of science-based rhetoric in discussing global warming that was leaked to the press in early 2003. The Luntz Research Companies, Straight Talk, The Environment: A Cleaner, Safer, Healthier America, at 138, available at http:/www.luntzspeak.com/graphics/LuntzResearch.Memo.pdf.

28. John D. Graham, Administrator, Office of Information and Regulatory Affairs, Office of Management and Budget, The Role of Precaution in Risk Assessment and Management: An 
the precautionary principle tend to describe precaution as the opposite of scientific decisionmaking. Gail Charnley and Donald Elliott, for example, characterize precautionary decisions as those made "in the absence of adequate science," and argue that such decisions should include some signal "that policy, not science, underlies those standards." ${ }^{29}$ In another paper, Charnley directly calls the precautionary principle anti-scientific. ${ }^{30}$ Frank Cross complains about "the disdain for scientific evidence" of precautionary principle advocates. ${ }^{31}$ In a similar vein, critics have accused the European Union of turning to "a simplistic vision of the precautionary approach to biotech crops" because "the traditional science of risk assessment was not on [its] side,",32 and the United Nations Food and Agriculture Organization has publicly worried that environmental groups would use the precautionary principle "as an argument to dismiss the role of science in fisheries management." Wall Street Journal editorial presented this criticism in its sharpest form: "The precautionary 'principle' is an environmentalist neologism, invoked to trump scientific evidence and move directly to banning things they don't like-biotech, wireless technology, hydrocarbon emissions." 34

American's View (Jan. 11-12, 2002), available at

http://www.whitehouse.gov/omb/inforeg/eu_speech.html.

29. Charnley \& Elliott, supra note 15, at 10,365. The characterization of precautionary decisionmaking as the polar opposite of a science-based approach so dominates legal scholarship that even thoughtful scholars sympathetic to the precautionary approach have adopted it. J.B. Ruhl, for example, lists "The Precautionary Principle Method" and "The Scientific Method" as two competing models for decisionmaking under the Endangered Species Act. J.B. Ruhl, The Battle Over Endangered Species Act Methodology, 34 ENVTL. L. 555, 556 (2004).

30. Professor Percival quotes Charnley as accusing the precautionary principle's "proponents of waging 'the newest skirmish in the age-old battle between empirical science and anti-empirical ideology."' Percival, supra note 3 , at 27, quoting President's Message, RISK NEWSLETTER (Soc'y for Risk Analysis, McLean, Va.), Third Quarter 1999, at 2.

31. Frank B. Cross, Paradoxical Perils of the Precautionary Principle, 53 WASH. \& LEE L. REV. 851,854 (1996).

32. Thomas P. Redick, Stewardship for Biotech Crops: Strategies for Improving Global Consumer Confidence, 44 JURIMETRICS J. 5 , 18 (2003).

33. Olav Schram Stokke \& Clare Coffey, Precaution, ICES and the Common Fisheries Policy: A Study of Regime Interplay, 28 MARINE POLICY 117, 118 (2004) (quoting FAO, PRECAUTIONARY APPROACH TO CAPTURE FISHERIES AND SPECIES INTRODUCTIONS, FAO TECHNICAL GUIDELINES FOR RESPONSIBLE FISHERIES 2 (1996)).

34. Editorial, Fear of the Future, WALL ST. J., Feb. 10, 2000, at A18. Ronald Bailey, who is associated with the Competitive Enterprise Institute and Cato Institute, echoes that view: "The precautionary principle is an anti-science regulatory concept that allows regulators to ban new products or technologies on the barest suspicion that they might pose some unknown threat." Ronald Bailey, Op-Ed, Food and Trade: EU Fear-Mongers' Lethal Harvest, L.A. TIMES, Aug. 18, 
Claims that a precautionary approach is "anti-scientific" or inconsistent with scientific principles rest on a category mistake. It is simply incoherent to compare "science" with "precaution." The two are different tools designed to serve different purposes. Science is a set of (ideally) value-neutral tools, a process for deepening our understanding of the natural world. It does not, and indeed cannot, tell us what we should do with that understanding. It can illuminate the consequences of policy choices, but it does not dictate those choices. Commentators who describe scientific decisionmaking as imposing a high standard of proof are grafting their own policy preferences onto the available scientific information. Precaution, on the other hand, is a moral argument that makes no pretense of value neutrality. It provides normative judgments about how information generated by science (including the limits and lingering uncertainties of that information) should be translated into individual or societal action. Science and precaution, in other words, are not substitutable in the decisionmaking process. They play different but equally necessary roles in that process. Science provides data. Precaution is one way to turn data into decisions. If science is the anvil, precaution is the moral hammer. ${ }^{35}$ One might choose a different hammer, a different anvil, or even a completely different approach to bending steel, but it makes no sense to criticize a hammer for not being a good anvil.

It is not surprising, however, that many commentators have done exactly that. The rhetoric of research science is easily misread to suggest that science provides a universal, objective filter for deciding how much information is needed to support a particular regulatory or management decision. Scientific research papers often speak of hypotheses as "proven" or "falsified" by the evidence. Social conventions or practice norms have developed in various fields of science to govern such assertions. The most widely recognized of these is the commonlyapplied standard that statistical tests must support a ninety-five percent confidence level that an observed effect did not arise by chance before a claim of proof is made. Regulatory skeptics take that confidence level as

2002, at M3.

35. Cf. Herman E. Daly, Introduction to the Steady-State Economy, in ECONOMICS, EcoloGY, ETHICS I, II (Herman E. Daly ed., 1980) ("Growth chestnuts have to be placed on the unyielding anvil of biophysical realities and then crushed with the hammer of moral argument. The entropy law and ecology provide the biophysical anvil. Concern for future generations and subhuman life and inequities in current wealth distribution provide the moral hammer.") (quoted in Christopher $\mathrm{H}$. Schroeder, Prophets, Priests, and Pragmatists, 87 MINN. L. REV. 1065, 1065 (2003)). 
an ineluctable, and entirely objective, element of a "scientific" approach to decisionmaking. In reality, though, the identification of levels of statistical "significance" is a subjective policy choice, reflecting nothing more profound than an implicit judgment by the relevant community about the relative costs of different sorts of errors. ${ }^{36}$ There is nothing incoherent or scientifically improper about choosing those levels, or the statistical tests to apply, in a more or less precautionary way. ${ }^{37}$

Viewing precaution and science as polar opposites magnifies two related mistakes we are already inclined to make. The first is assuming that the application of science, or quantitative cost-benefit analysis or some other "rational" technique, can guarantee objective decisions. Judgment is inevitably required to interpret or understand scientific data. ${ }^{38}$ The more incomplete or inconclusive the data, the more the judgments will vary with the subjective preferences or biases of the interpreter. $^{39}$ Ultimately values, not formulas, must determine our environmental policy decisions, just as they determine other important policy choices. The second mistake is believing that strong objectivity is a necessary element of principled environmental decisionmaking. We seem to fear that unless environmental policy decisions are so objective as to be computable by formula, they will not be grounded in anything other than the whim or preference of the decisionmaker. As David Dana has pointed out, however, in other areas, even those that lie at the core of our democratic tradition, we do not demand determinacy. ${ }^{40}$ Pining obsessively for unachievable objectivity in environmental policy gets in the way of an honest search for useful decisionmaking principles.

36. See, e.g., Thomas O. McGarity, Substantive and Procedural Discretion in Administrative Resolution of Science Policy Questions: Regulating Carcinogens in EPA and OSHA, 67 GEO. L.J. 729, 748-49 (1979); John Lemons et al., The Precautionary Principle: Scientific Uncertainty and Type $I$ and Type II Errors, 2 Found. OF SCI. 207, 227-30 (1997); Holly Doremus, Science Plays Defense: Natural Resource Management in the Bush Administration, 32 EcologY L. Q. 249, 262-64 (2005).

37. See Daniel J. McGarvey, Merging Precaution with Sound Science Under the Endangered Species Act, 57 BIOSCIENCE 65 (2007) (advocating the use of statistical equivalence tests, rather than hypothesis tests, in ESA implementation in order to better recognize and take account of the dangers of false negative results).

38. That judgment plays an essential role in scientific practice has been widely recognized since Thomas Kuhn published his influential book, The Structure of Scientific Revolutions.

39. See Holly Doremus, Listing Decisions Under the Endangered Species Act: Why Better Science Isn't Always Better Policy, 75 WaSH. U. L. Q. 1029, 1068 (1997); Holly Doremus \& A. Dan Tarlock, Science, Judgment and Controversy in Natural Resource Regulation, 26 PUB. LAND \& RESOURCES L. REV. 1, 8-11 (2005).

40. Dana, supra note 3 , at 1318. 


\section{The True Strength of Science Lies in Its Capacity to Promote Learning}

Although a scientific approach to decisions cannot provide absolute objectivity, it can and should promote and support learning. As I have written elsewhere:

The essence of science is not objective certainty. It is, instead, a process carefully designed to illuminate the extent and reliability of knowledge about studied systems, and to increase the reliability and extent of that knowledge over the course of time. ${ }^{41}$

In other words, what science provides is a structured process designed to identify gaps in understanding and facilitate learning over time.

The potential for learning has too often been ignored in environmental regulation and natural resource management. Although some uncertainties will always remain, it is not true that all of the uncertainties that plague policy choices are irreducible. Careful application of scientific techniques should enhance learning about managed systems. Generally, a scientific approach requires developing and testing hypotheses about how those systems work. Hypotheses need not be detailed or elaborate. Testing by controlled experimentation produces the most robust results. Opportunities for experiments are limited in natural systems, however, because confounding variables cannot practically be controlled and risks to protected resources may impose limits on manipulation. Even severe limits on experimentation, however, do not amount to prohibitions on learning. Other techniques, including current and historical observations, ${ }^{42}$ manipulation of models, laboratory experiments, and analogies from similar or related systems, may offer useful information.

Scientific learning is a complex process that does not happen automatically. There are any number of points in the process where things can go wrong. ${ }^{43}$ Simply recognizing that attention to learning,

41. Doremus, Science Plays Defense, supra note 36, at 297.

42. One intriguing example of attempts to integrate historical data into modem resource management comes from the history arm of the multidisciplinary Census of Marine Life. One of three major prongs of the Census is the History of Marine Animal Populations project, which "collects and interprets historical records to build pictures of past oceanic conditions" in order to inform goals for ocean sustainability. Katharine Anderson, Does History Count?, 30 ENDEAVOUR $150,150(2006)$.

43. I describe some of the challenges of generating scientific information and making sure that 
rather than perfectly objective decisionmaking, is the fundamental hallmark of a scientific approach will not guarantee that we learn more. But it will surely encourage us to pay more attention to what learning can do for us and how we might promote it in particular contexts.

\section{The Synergistic Potential of Precaution and Science}

Neither science nor precaution alone provides a reliable guide to natural resource management. Because each addresses important shortcomings in the other, however, they are synergistic. Science reminds precaution that fear need not be paralyzing and that action need not mean the complete loss of regulatory control. Precaution reminds science to be humble about the limits of current understanding and open to the full range of possible explanations. For many natural resource decisions, the two together point in the direction of emphasizing learning in the course of action.

\section{How Science Can Improve Precaution}

The two most telling criticisms of precautionary decisionmaking are that it can cause paralysis and that it papers over choices between competing risks. Bringing scientific evaluation of the possibilities for learning to bear can help address these closely intertwined criticisms.

Cass Sunstein is the most prominent critic of the paralyzing tendency of precaution, which he attributes to the fact that alternative choices often pose competing risks. If the precautionary principle were applied in the strong form advocated by some, to bar any action that poses significant risks, it would seem to prohibit the introduction of such desirable new technologies as electricity, automobiles, and immunization. ${ }^{44}$ But, Sunstein points out, foregoing those technologies poses its own risks. Although immunization may cause disease in a fraction of those vaccinated, without it epidemics may rage unchecked. Similarly, the conventional practice of disinfecting drinking water by chlorination produces detectable quantities of toxic organochlorine

information is available for and considered in decisionmaking in Holly Doremus, Data Gaps in Natural Resource Management: Sniffing for Leaks Along the Information Pipeline, INDIANA L. REV. _ (forthcoming 2007).

44. SUNSTEIN, supra note 7, at 25. See also Cross, supra note 31 (arguing that health and environmental regulation often produces unanticipated adverse health and environmental consequences). 
compounds and brings the risk of a major accidental release of gaseous chlorine during transport, ${ }^{45}$ but leaving water untreated puts the public at risk of waterborne diseases. In situations where both action and inaction pose risks, Sunstein argues that strong forms of the precautionary principle "stand[] as an obstacle to regulation and nonregulation, and to everything in between." 46

Sunstein's major answer to the potential for precautionary paralysis is to call for cost-benefit analysis to highlight the trade-offs inherent in choices between alternative actions. But where the available information about the consequences of action is highly uncertain, as it must be to justify invoking precaution, cost-benefit analysis adds little decisionmaking power. ${ }^{47}$ Sunstein himself has recognized the notorious indeterminacy of cost-benefit analysis, writing that the benefits of EPA's arsenic regulation could reasonably be estimated at anywhere from $\$ 10$ million to $\$ 1.2$ billion. $^{48}$ It is difficult to see how estimates with uncertainty ranges as high as 10 orders of magnitude add anything to the simple recognition that arsenic might or might not pose a significant human health risk.

Because most natural resource decisionmaking is dynamic, however, the possibility of learning offers a way out of paralysis that cost-benefit analysis does not. Where the need to act is combined with uncertainty about the consequences of alternative actions, one key question is whether uncertainty might be reducible, at what cost, and on what time scale. A second is how quickly and irreversibly alternative choices are likely to commit us to environmental harm. If there is some prospect of useful learning and some room for incremental action while we address information gaps, learning while doing takes advantage of the best features of both precaution and science.

Suppose, for example, that we are uncertain whether to allow planting of "Bt corn," corn genetically engineered to contain a natural insecticidal protein derived from the bacterium Bacillus thuringensis $(\mathrm{Bt})$. Potential environmental risks include development of insect resistance to $\mathrm{Bt}$,

45. See Paul Orum, Toxic Trains and the Terrorist Threat: How Water Utilities Can Get Chlorine Gas Off the Rails and Out of American Communities (Apr. 2007), available at http://www.americanprogress.org/issues/2007/04/pdf/chemical_security_report.pdf (detailing the risks of a major accident in the transportation of chlorine).

46. SUNSTEIN, supra note 7 , at 33 .

47. Gregory N. Mandel \& James Thuo Gathii, Cost-Benefit Analysis Versus the Precautionary Principle: Beyond Cass Sunstein's Laws of Fear, 2006 U. ILL. L. REV. 1037, 1045.

48. Cass R. Sunstein, The Arithmetic of Arsenic, 90 GEO. L.J. 2255, 2258 (2002). 
increased mortality of non-target organisms, and human or animal health impacts as Bt grains are introduced into the feed and food supply. When $\mathrm{Bt}$ crops were first developed, it was difficult to estimate either the probability or the potential magnitude of these harms, or the effectiveness of measures that might mitigate or prevent them. On the other side of the equation, use of $\mathrm{Bt}$ corn has the potential to reduce dependence on traditional chemical pesticides more toxic to humans. Furthermore, if $\mathrm{Bt}$ corn controls the European corn borer, the major insect pest of corn, more effectively than chemical treatments, that could produce an indirect human health benefit. High levels of corn borer damage facilitate the establishment of Fusarium, a fungal disease of corn, both by directly carrying the fungus into corn ears and by opening holes that can provide pathways for airborne infection. Some Fusarium species produce a toxin known as fumonisin. Dietary intake of fumonisin has been linked to certain types of cancers and birth defects, especially in Mexican-American women who consume large quantities of unprocessed corn. Some field studies have shown lower levels of fumonisin in Bt than in non-Bt corn lines. ${ }^{49}$ Like the risks, these potential benefits were highly uncertain when $\mathrm{Bt}$ corn was first developed.

In the United States, crops engineered to express Bt proteins are regulated as pesticides under the Federal Insecticide, Fungicide, and Rodenticide Act (FIFRA). ${ }^{50}$ Like other pesticides, Bt corn lines may not be lawfully sold until they are formally registered. ${ }^{51}$ Registration requires a finding that the pesticide, "when used in accordance with widespread and commonly recognized practice... will not generally cause unreasonable adverse effects on the environment." 52 That judgment, which requires a balancing of risks and benefits, is obviously difficult to make when both are uncertain.

FIFRA allows EPA to deal with uncertainty through a precautionary learning approach. ${ }^{53}$ EPA can issue experimental use permits to allow

49. This discussion of the potential indirect health benefits of Bt corn is drawn from Drew $\mathrm{L}$. Kershen, Health and Food Safety: The Benefits of Bt-Corn, 61 FoOD \& DRUG L.J. 197, 198-206 (2006).

50. 7 U.S.C. $\S \S 136-136 y(2006)$.

51. 7 U.S.C. $\$ 136 a(a)$.

52. 7 U.S.C. $\S 136 \mathrm{a}(\mathrm{c})(5)$.

53. For a concise and lucid description of the FIFRA registration process, see Mary Jane Angelo, Embracing Uncertainty, Complexity and Change: An Eco-Pragmatic Reinvention of a FirstGeneration Environmental Law, 33 ECOLOGY L.Q. 105 (2006). 
field testing designed to generate information. ${ }^{54}$ It can conditionally register a pesticide while additional data are gathered. Special restrictions can be imposed during the period of conditional registration to protect against unreasonable adverse effects. ${ }^{55}$ EPA can also limit and impose conditions on uses through labeling restrictions, which FIFRA requires users to follow. ${ }^{56}$ Even after full registration, EPA can require registrants to submit additional data, on pain of suspension of registration. $^{57}$

EPA could have used its FIFRA authorities to, for example, experiment with different insect refuge strategies for limiting development of resistance, require close monitoring of impacts on nontarget organisms, set up and test mechanisms for tracking Bt corn after harvest, or monitor the levels of fungal toxins in Bt corn products. Any of those steps could enhance learning. Identifying measures likely to fill major information gaps and allowing experimental use or conditional registration while those measures were implemented would have been both scientifically sound and precautionary. It would have facilitated the efficient development of stronger information about both the risks and benefits of $\mathrm{Bt}$ corn without unduly delaying the introduction of a potentially useful new technology. That the saga of Bt corn has played out without such a focus on learning ${ }^{58}$ speaks to the challenges of implementing a precautionary learning approach. Those challenges are addressed below.

\section{How Precaution Can Improve Science}

Just as precautionary decisionmaking can gain legitimacy from attention to science, scientific decisionmaking can benefit from the dose of humility that attention to precaution brings. Scientists are no more perfect than the rest of humanity. They suffer from many of the same ingrained cognitive biases that plague others. Their focus on data helps scientists battle some of these biases, but their expertise actually makes them more prone than others to one particular bias: "overconfidence in

54. 7 U.S.C. $\S 136 \mathrm{c}$.

55. 7 U.S.C. $\S 136 \mathrm{a}(\mathrm{c})(7)$.

56. 7 U.S.C. $\S 136 \mathrm{j}(\mathrm{a})(2)(\mathrm{G})$.

57. 7 U.S.C. $\S 136 \mathrm{a}$ (c)(2)(B)(i)-(iii).

58. See Rebecca Bratspies, The Illusion of Care: Regulation, Uncertainty, and Genetically Modified Food Crops, 10 N.Y.U. ENVTL. L.J. 297 (2002) (describing the reluctance of EPA to develop, impose, or monitor structured refuge requirements for Bt corn). 
their own judgments." 59 Experts are "often wrong but rarely in doubt."60 Experts also tend to overestimate the importance of their field of expertise and to underestimate what other perspectives might bring to the problem. ${ }^{61}$ In a word, experts, including scientists, are prone to hubris.

That can be problematic for the progress of scientific knowledge in general, but particularly for policy decisions that require a sound scientific understanding of the natural world. It can reinforce the type of uncertainty Brian Wynne calls "ignorance," which encompasses the aspects of a problem that we not only do not understand, but that we are also not even aware that we do not understand. ${ }^{62}$ Wynne provides an example from the aftermath of the Chernobyl incident. As the radioactive cloud passed over Wales, rain brought radioactive cesium down over upland areas. Scientists assured the public that there would be no lasting effects, but several weeks later a ban was suddenly imposed on the slaughter and sale of sheep from the hill areas. Wynne explains that, based on past observations, scientists had assumed that cesium would quickly become immobilized in the soil. But it turned out that their knowledge was incomplete. Earlier observations had all been made in alkaline soils, but the Welsh hill soils were acidic. ${ }^{63}$ Scientists had assumed that they understood how cesium behaved in soils. Their knowledge blinded them to their ignorance; they had not realized that their understanding was limited to behavior in a restricted class of soils.

A truly precautionary approach would help experts (both inside and outside of regulatory agencies) keep in mind the potential for these sorts of biases and thereby stay open to new and unexpected knowledge. Precaution can maximize the likelihood that decisionmakers will notice and take advantage of opportunities for learning by serving as a constant reminder of the limits of current information.

59. Dana, supra note 3, at 1333; Jeffrey J. Rachlinski \& Cynthia R. Farina, Cognitive Psychology and Optimal Government Design, 87 CORNELL L. REV. 549, 560-61 (2002).

60. Dale Griffin \& Amos Tversky, The Weighing of Evidence and the Determinants of Confidence, 24 COGNITIVE Psychol. 411, 412 (1992).

61. Rachlinski \& Farina, supra note 59 , at 560.

62. Brian Wynne, Uncertainty and Environmental Learning: Reconceiving Science and Policy in the Preventive Paradigm, 2 GloBal ENVTL. CHANGE 111, 114 (1992).

63. Id. 


\section{A FRAMEWORK FOR LEARNING WHILE DOING IN RESOURCE MANAGEMENT}

In situations where action is perceived to be necessary but its consequences are uncertain, both an urge toward precaution and a commitment to science suggest that we look for ways to act incrementally while learning. That, of course, is easier said than done. In this part, I explain my terminology, sketch the rough outlines of a learning-while-doing approach, and offer some suggestions for how executive, legislative, and judicial actors could help agencies surmount the considerable barriers to adopting such an approach.

\section{A. Adaptive Management By Any Other Name?}

Learning while doing is hardly a new concept. In many ways it is what Charles Lindblom described as "muddling through" in a celebrated 1959 paper, by contrast with the academic ideal of comprehensively rational decisionmaking. ${ }^{64}$ Learning while doing would also seem to be at the core of proposals for adaptive management, an idea often appealed to but rarely achieved in natural resource management. The essence of adaptive management, according to J.B. Ruhl, is "an iterative, incremental decisionmaking process built around a continuous process of monitoring the effects of decisions and adjusting decisions accordingly." Adaptive management gets away from the conventional "front-loaded" approach to regulation. It emphasizes the need for learning and reevaluation. It combines, one might think, precaution with science.

I have chosen not to use either Lindblom's term or the currently trendy one because both carry baggage I wish to jettison. Lindblom was too optimistic about the commitment of managers to learning and their skills in doing so. He believed he was describing the usual practice when he wrote that decisionmakers proceed incrementally, on the bases of knowledge gained from past small steps about the consequences, testing their predictions as they move on, and remaining always ready to remedy past failures. ${ }^{66}$ History shows, however, that such learning

64. Charles E. Lindblom, The Science of "Muddling Through," 19 PUB. ADMIN. REV. 79 (1959).

65. J.B. Ruhl, Regulation By Adaptive Management-Is It Possible? 7 MNN. J. L. SCI. \& TeCH. 21, 28 (2005).

66. See Lindblom, supra note 64 , at 86. 
systematically does not occur in natural resource management. Left to their own devices, decisionmakers tend only to look forward. Writing about water projects, Jeffrey Jacobs reminds us that

[d]espite the potential benefits of incorporating past results into future planning and operations, agencies shun historical ex post reviews for several reasons: public criticism of projects under construction tends to inhibit project proponents from studying impacts, administrators tend to avoid exercises that might cast them in a negative light or be unduly expensive, water project effects are not always clearly manifest or understood, and the multidisciplinary knowledge required to comprehensively evaluate a project or program is rarely found within a single organization. $^{67}$

Similar dynamics impede learning in other natural resource contexts. In reality, then, Lindblom's "muddling through" tends to reduce to action without learning.

The term "adaptive management" is also tainted. It has been co-opted in two distinct ways. On the management side, it has been used to emphasize the need to act while downplaying the role of learning. Promises of adaptive management have become excuses to act in the face of uncertainty, providing empty assurances of environmental protection without any enforceable requirements for learning or incorporating new knowledge. ${ }^{68}$

From the scientific side, the term "adaptive management" suffers from a different problem. Some architects of the adaptive management movement have so emphasized one particular path to learning, largescale management experiments, that it has become almost a fetish and a barrier to less ideal but more practical paths. As noted above, even small management experiments face daunting barriers in many systems. Experiments are by nature risky and their impacts may be irreversible. Failure could harm, rather than benefit, protected resources. Managers may quite reasonably fear that success would go unnoticed but failure would be severely punished.

Maximizing learning requires sensitivity to such very real barriers. Rather than reflexively criticizing managers who fail to undertake

67. Jeffrey W. Jacobs, Broadening U.S. Water Resources Project Planning and Evaluation, 42 NAT. RESOURCES J. 21, 22 (2002).

68. See Holly Doremus, Adaptive Management, the Endangered Species Act, and the Institutional Challenges of "New Age" Environmental Protection, 41 WASHBURN L.J. 50, 53 (2001). 
management experiments, we should ask whether experimentation is possible and if so whether its benefits justify its costs. I have deliberately used the term "learning while doing" rather than "learning by doing" to emphasize that there are many routes to knowledge. Managers should be encouraged to broadly examine all the possibilities for learning and to be prepared to exploit those that appear most useful in a particular situation. Where experiments are scientifically difficult or politically unacceptable, managers should consider less invasive techniques, including modeling, laboratory work, extrapolation from other systems, and mining historical data.

\section{B. What Does Learning While Doing Require, and How Can We Get There?}

There are any number of reasons why management-relevant learning does not occur. Some information gaps, I freely concede, are simply too broad to be bridged on relevant time scales. But in many other situations we fail to take advantage of available opportunities for learning. Regulatory and management agencies do not naturally adopt a learning focus. Barriers include lack of funding, lukewarm support (at best) from above and below, opposition from political constituencies, and institutional structures and cultures that do not reinforce or reward learning. A push toward learning is needed, together with the resources and culture to support learning. The needed elements are not likely to come from a single source. Agency leaders, legislatures, and courts can all contribute.

\section{Agency Discretion and Leadership}

Agencies frequently enjoy sufficient discretionary authority to put a commitment to learning while doing in place. ${ }^{69}$ I pointed out earlier the extent to which FIFRA allows a learning-based approach to pesticide registration. The laws under which public lands and other natural resources are managed often provide even more discretion. Agencies

69. There are, of course, exceptions. The general requirement that the Army Corps of Engineers turn non-navigational projects over to non-federal sponsors after construction, for example, imposes a serious check on the ability of the Corps to engage in structured learning relevant to operation of those projects. See NAT'L RESEARCH COUNCIL, ADAPTIVE ManagemENT FOR Water RESOURCES Project PlanNING 44 (2004). In general, however, a great deal of discretionary authority to promote leaming goes unused. 
may even have the ability to advance learning by interpreting the laws they implement as imposing obligations for information production. ${ }^{70}$

At the same time, agencies typically enjoy enough discretion to allow them to perpetuate ignorance. Unless learning is systematically rewarded by the legislature or the highest levels of the executive branch-which is rare-there is little external incentive for agency leaders to buck tradition. Internal incentives are likely to run the other way. Moving to an active learning approach requires resources and trained personnel. A strong learning while doing approach to $\mathrm{Bt}$ corn regulation, for example, would have required that EPA design and oversee experiments testing the effectiveness of alternative structures for insect refuges in delaying the evolution of resistance. Experimental design and oversight is an unfamiliar task for agencies and likely to prove resource-intensive.

Effective leadership can help move agencies toward a greater commitment to learning. Such a move requires leaders who have both the motivation to push learning and the personality to carry it off. The right personality is largely an accident of birth. In order to take advantage of the discretion that allows agency learning, leaders must be skilled salespeople able to persuade superiors, subordinates, and funders of the value of learning. The motivation to push learning is likely to be a product of training and experience. It can come from a strong commitment to the agency mission, combined with two other factors: the firm conviction that achieving the mission requires learning, and the awareness of the systematic barriers that make learning difficult. That combination is most likely to be found in someone whose background combines real-world agency experience with close contact with highquality scientific work, or vice versa. One example is Samuel Luoma, the first Lead Scientist of the short-lived CalFed Bay-Delta state-federal cooperative management experiment. Prior to joining CalFed, Luoma was a career scientist at the United States Geological Survey (USGS). USGS is not a regulatory agency, but Luoma had also tasted the challenges of regulatory work through service on scientific advisory panels to EPA. With the help of generous funding dedicated to science, Luoma used standing scientific review boards, targeted grant funding

70. Cf. Holly Doremus, The Purposes, Effects, and Future of the Endangered Species Act's Best Available Science Mandate, 34 ENVTL. L. 397, 444 (2004) (arguing that the ESA could be administratively interpreted in such a way as to provide far stronger incentives for information production). 
opportunities, and monitoring and performance measures to instill a culture of scientific learning at CalFed. ${ }^{71}$

\section{Legislatures and Budgeting}

Legislatures can take a variety of steps to encourage learning while doing. They can, and frequently do, require that agencies act on the basis of the "best available scientific information." 72 Such mandates serve both to require that agencies confront the latest scientific findings when they make decisions and to protect against the paralyzing search for ever-better scientific support. Legislatures can mandate specific studies when they recognize key data gaps. ${ }^{73}$ Like agency leaders, legislatures can invoke outside expert review or periodic public reporting requirements as incentives for learning. They can explore a variety of other mechanisms for rewarding learning and punishing intellectual complacency.

By far the most important contribution legislatures can make to learning while doing, however, is to support it through stable and sufficient funding sources. Without targeted funding for new research, as well as for interpretation and wide sharing of data, "best available science" mandates can have the unintended effect of freezing the state of knowledge. Funding is one of the biggest challenges for management research programs. Legislatures, which control the purse strings, seem systematically inclined to target funding toward action to the exclusion

71. See Katherine L. Jacobs et al., CalFed: An Experiment in Science and Decisionmaking, ENV'T, Jan.-Feb. 2003, at 30. For a general description of the CalFed Science Program as initially conceived, see CalFed Bay-Delta Program, Programmatic Record of Decision 74-76 (Aug. 28, 2000), available at http://calwater.ca.gov/Archives/GeneralArchive/rod/ROD8-28-00.pdf. An impressive testament to the Science Program is that it has proven enduring enough to survive the collapse of the state-federal partnership.

72. Best available science requirements are found in, among others, the Endangered Species Act, Marine Mammal Protection Act, and the Magnuson-Stevens Fishery Conservation and Management Act. For a partial listing of federal best available science mandates, see Doremus, supra note 70, at 405 n.45 (2004).

73. In 1997, for example, Congress amended the Marine Mammal Protection Act to direct the National Oceanic and Atmospheric Administration (NOAA) to carry out three specific studies-a review of stress-related research and dolphin necropsy samples; a review of historical data; and an experimental study of the effects on dolphins of repeated chasing and capturing-before determining whether to expand the "dolphin-safe" tuna label to cover tuna fishing techniques that involve encircling but not directly killing dolphins. 16 U.S.C. $\$ 1414 a(a)(3)(2006)$. The Ninth Circuit recently held that NOAA must conduct the required studies with a sufficient sample size to support population-level inferences about the impact of encirclement on dolphins. Earth Island Inst. v. Hogarth, 484 F.3d 1123, 1131 (9th Cir. 2007). 
of learning. Made up as they are of political actors with short time horizons, legislatures understandably crave immediate results. They tend to see action, rather than research or monitoring, as the most likely source of such results. In addition, legislatures may be attuned to the desires of those who benefit from the status quo-those who may strongly oppose the devotion of additional resources to discovering information that increases the likelihood of regulation.

Clearly, there are substantial barriers to funding learning. A few recent high-profile examples suggest that the politics can be overcome in the right situation but that it is difficult to maintain funding in the long run. The original CalFed Record of Decision called for dedicating a generous proportion of the agency's funding to the science program. Later, though, those promises did not turn into hard cash. A source of resources outside the annual appropriations free-for-all is likely to be an essential element of any successful long-term program of learning. In some circumstances, part of that money might come from user or development fees. It seems entirely fair, for example, that the Metropolitan Water District, which receives one-half of the water supplied by the California State Water Project, ${ }^{74}$ should finance a substantial share of the studies needed to better understand how operation of the Project can be consistent with a healthy Delta ecosystem. In other instances, support might come from federal or state science funding agencies. Where the United States has been a major contributor to the development of conditions that make learning necessary, as is the case with forest fire hazards, it may be fair to spread the costs of targeted applied science to the taxpaying public at large.

\section{Courts and Incentives for Learning}

The courts, too, have a particular role to play in encouraging learning while doing. Judicial review can help counter the entrenched incentives agencies have to avoid learning. To get the incentives right, courts must balance two conflicting urges. On one hand, in order not to impose paralysis, they should avoid unrealistic expectations about ex ante

74. California Department of Water Resources, Bay-Delta Office, The State Water Project Delivery Reliability Report 2005, Final, at D-11 (Apr. 2006), available at http://baydeltaoffice.water.ca.gov/swpreliability/SWPRel05_final.pdf. The Metropolitan Water District "is a consortium of 26 cities and water districts that provides drinking water to nearly 18 million people" in southern California. Metropolitan Water District, About MWD, http://www.mwdh2o.com/mwdh2o/ pages/about/about01.html. 
synoptic information gathering and digestion. Deference to plausible agency guesses about how systems work or the impacts of particular management decisions is warranted early in the iterative decisionmaking process, before the agency has had substantial opportunities for learning. On the other hand, it is important that courts not fall into the trap of blind deference to agency guesses in the face of uncertainty, which can encourage deliberate strategic ignorance. Courts must push agencies to seek useful knowledge where it appears practical to do so.

The Ninth Circuit's decision in Ecology Center v. Austin ${ }^{75}$ illustrates the need for and challenges of finding a middle way. The dispute stemmed from the Forest Service's decision to implement a thinning and prescribed burning project in old growth stands in Montana's Lolo National Forest. The issue was whether the project was consistent with the forest plan's requirement to maintain viable populations of oldgrowth-dependent species. The Forest Service pointed to studies indicating that treatment was "necessary to correct uncharacteristic forest development resulting from years of fire suppression." ${ }^{176}$ Ecology Center responded that even if the treatment would bring the forest closer to its historic structure, it could alter habitat elements essential to oldgrowth species. As the panel majority characterized the evidence, neither side "offer[ed] proof" 77 that the treatment would help or harm oldgrowth species. The Forest Service had not "directly monitored the impact of treating old-growth on dependent species," although it did cite a report noting that two species of woodpecker had been seen foraging in treated areas. ${ }^{78}$ The Forest Service relied chiefly on what it characterized as a reasonable assumption that old-growth dependent species would not be harmed based on what was known about the effects of treatment on forest composition. ${ }^{79}$

The panel majority refused to defer to that assumption. Its rationale merits an extended quotation:

[T] he Forest Service's conclusion that treating old-growth forest is beneficial to dependent species is predicated on an unverified hypothesis. While the Service's predictions may be correct, the Service has not yet taken the time to test its theory with any on

75. 430 F.3d 1057 (9th Cir. 2005).

76. Id. at 1063 .

77. $1 d$.

78. Id.

79. Id. 
the ground analysis, despite the fact that it has already treated old-growth forest elsewhere and therefore has had the opportunity to do so... This is not a case in which the Forest Service is asking for the opportunity to verify its theory of the benefits of old-growth treatment. Rather, the Service is asking us to grant it the license to continue treating old-growth forests while excusing it from ever having to verify that such treatment is not harmful ...

Although the Service concedes that the opinions of wellqualified experts vary with respect to the appropriateness of management activities in old-growth areas, it also argues that it must have the discretion to rely on the reasonable opinions of its own qualified experts even if, as an original matter, a court might find contrary views more persuasive. However, this is not a case in which different experts have studied the effects of commercial thinning and prescribed burning in old-growth forests and reached different conclusions. Here, experts have differing hypotheses regarding the effects that treating oldgrowth has on dependent species, yet the Forest Service proposes to continue treating old-growth without first taking the time to observe what those effects actually are. In light of its responsibilities under [the National Forest Management Act], this is arbitrary and capricious. ${ }^{80}$

Judge McKeown dissented, noting that the Forest Service had supported its hypothesis with direct observation of the composition and structure produced by treatment. ${ }^{81}$

The situation in Ecology Center is precisely the sort that calls for learning while doing. The Forest Service contended that not treating the old-growth stands would leave them at risk of insect infestation, disease, and high-severity fire, any one of which could destroy their suitability as habitat for old-growth-dependent species. Yet the treatment proposed could also harm the same species. It is not obvious which decision, to treat or not to treat, would be "precautionary." This is a situation in which Sunstein's paralysis critique has genuine force-if the applicable forest plan required that the Forest Service not act in a way that would put old-growth dependent species at risk, the Service might literally be forbidden either to treat or not to treat old-growth stands. Indeed, Judge

80. Id. at 1064-65 (quotations and citations omitted).

81. Id. at 1076 (McKeown, J., dissenting). 
McKeown contended that the Forest Service could just as easily have been accused of arbitrary and capricious decisionmaking for not treating the stands as for treating them. ${ }^{82}$

But this is also a situation in which science offers an alternative to paralysis. As the majority noticed, the Forest Service faced the same decision at a number of other sites. It had already treated some of those sites by methods similar to those it proposed to use in the challenged project. The Forest Service apparently had not carefully monitored the effects of its projects on the species it was supposed to protect. Nor had it framed any of its treatment projects as tests of its hypothesis about the impacts of treatment on old-growth species. In the absence of any explanation for why such studies would be impractical, the panel majority was right to demand more of the Service.

Reasonable minds can surely disagree, on the facts as described in the competing opinions, as to whether the Forest Service had shown enough supporting evidence to justify deference to its hypothesis. Judges seeking to encourage agency learning without intruding on agency decisionmaking discretion will inevitably face difficult line-drawing exercises. But the basic intuition motivating the majority-that the Service should be required to test its hypotheses if it is practical to do so and if the substantive correctness of management decisions depends on their accuracy-is sound.

This intuition might be applicable under a range of statutes and in a range of circumstances. For now, though, we might consider just one additional example, the Seventh Circuit's much-criticized decision in Sierra Club v. Marita. ${ }^{83}$ In Marita, Sierra Club alleged that the Forest Service violated the National Forest Management Act and National Environmental Policy Act by "arbitrarily disregarding certain principles of conservation biology in developing" land and resource management plans for two national forests in Wisconsin. ${ }^{84}$ Essentially, the Forest Service assumed that greater habitat diversity would mean greater species diversity, ${ }^{85}$ an assumption that allowed it to conclude that the management plans were consistent with maintaining viable populations of vertebrate species, as required by the forest planning regulations then

82. Id. at 1077 (McKeown, J., dissenting).

83. 46 F.3d 606 (7th Cir. 1995).

84. Id. at 614 .

85. Id. at 617 . 
in effect, even though the road building and timber harvest they contemplated would produce a high level of fragmentation.

Sierra Club argued that the Forest Service should also have been required to consider concepts from conservation biology and island biogeography, such as the role of edge effects and small patch size in limiting diversity ${ }^{86}$ To support that position, Sierra Club offered more than 100 articles from the scientific literature. Two professional societies, the American Institute for Biological Sciences and the Society for Conservation Biology, weighed in as amici on Sierra Club's side. ${ }^{87}$ The Forest Service responded that conservation biology had "not been applied to forest management in the Lake States," and argued that while the theory of island biogeography was "of interest ... there [was] not sufficient justification at [the] time to make research of the theory a Forest Service priority." 88

The court held that the Forest Service's failure to employ principles of conservation biology was not arbitrary or capricious. It observed that "[t]he Service is entitled to use its own methodology, unless it is irrational." 89 In this case, the court believed the Forest Service's explanation satisfied that limited standard.

Marita is a difficult case to parse, in part because the opinion wanders back and forth between disagreements about goals and disagreements about methods of ensuring that those goals are achieved. Much of the opinion seems to be motivated by deference to the Forest Service's understanding of what "diversity" should mean, which differed from Sierra Club's. Nonetheless, the opinion can be read to endorse deliberate (and convenient) ignorance on the part of the Forest Service. It allowed the Forest Service to avoid confronting the implications of island biogeography for its management plans because that theory

had been developed as a result of research on actual islands or in the predominantly old-growth forests of the Pacific Northwest and therefore did not necessarily lend itself to application in the forests of Wisconsin ... [H]owever valid a general theory may be, it does not translate into a management tool unless one can

86. $1 d$.

87. See Erin Madden, Seeing the Science for the Trees: Employing Daubert Standards to Assess the Adequacy of National Forest Management Under the National Forest Management Act, $18 \mathrm{~J}$. ENVTL. L. \& LITIG. 321, 341 (2003).

88. Marita, 46 F.3d at 618-19 (quoting the Forest Service's briefs).

89. Id. at 621 
apply it to a concrete situation. The Service acknowledged the developments in conservation biology but did not think that they had been shown definitively applicable to forests [in the Great Lakes]. Thus, circumstances did not warrant setting aside a large portion of these forests to study island biogeography and related theories at the expense of other forest-plan objectives. ${ }^{90}$

The problem with the Seventh Circuit's approach in Marita is that, unlike the Ninth Circuit's in Ecology Center, it leaves the Forest Service in complete control of whether its hypotheses about the relationship between fragmentation and diversity are ever tested. Perhaps the Sierra Club or a local academic could monitor the impacts on wildlife as the Forest Service implements its plans for these forests, but without the opportunity to make a comparison with the large reserves the Forest Service refused to create, that evidence would never be "definitive." It is unlikely that plaintiffs could find a sufficiently large area of similar forest outside the Forest Service's control to independently test their theories to the Forest Service's satisfaction.

That is not to say, however, that just because there was an opportunity for learning the court should have required the Forest Service to seize it. That is too simplistic. Sierra Club demanded that the Forest Service set aside twenty-five percent of each of two Great Lakes national forests as large undisturbed reserves. ${ }^{91}$ That would obviously have cut back substantially on the Service's ability to achieve its other goals. Although Sierra Club argued that such large reserves would better protect diversity, the opinion does not indicate that Sierra Club submitted evidence that any species could not be successfully maintained on the forests without them.

From a precautionary learning perspective, it is not clear that the Marita decision was wrong. It is clear, however, that it should have been approached differently, both by Sierra Club and by the court. There should have been a closer focus on whether the Forest Service would need to know if Sierra Club was right about the teachings of conservation biology in order to comply with its mandate, on these forests and others, to maintain viable wildlife populations (as required by the forest planning regulations in effect at the time). If, as seems likely, the effect of fragmentation on viability was an important issue, the next question should have been whether the competing hypotheses

90. Id. at $622-23$.

91. Id. at 618 . 
could be tested by methods other than putting a quarter of the forest off limits to harvest. If so, the court might have said that it would not defer to the next claim of uncertainty about the impact of island biogeography (again on these forests or others) unless the Forest Service tried to test its hypothesis or explained why it could not do so.

\section{CONCLUSION}

Dealing with uncertainty is the signature challenge of environmental and natural resource decisionmaking. Too often, however, uncertainty is treated as an entirely ex ante problem requiring only that the decisionmaker choose an appropriate burden of proof to apply to gatekeeping decisions. Although that aspect of decisionmaking under uncertainty will always be important, it has been allowed to obscure the problem of learning, which is at least as important for natural resource management. Serial, iterative, and similar decisions can be improved over time by structured learning.

Both the impulse toward caution and healthy respect for the ability of scientific inquiry to advance knowledge favor learning while doing when uncertainty is high but inaction is impractical or undesirable. Acting incrementally with attention to the feasibility and potential value of learning is the appropriate form of caution in such circumstances. Learning while doing is an unfamiliar process for resource management agencies but one with great potential value for achieving conservation objectives at the lowest practical sociopolitical cost. Notwithstanding the apparent value of learning while doing, it is not surprising that agencies have so far resisted that approach. It will take a combination of leadership, funding, and judicial prodding to make learning the norm rather than the exception. 
